\title{
PENGARUH PENAMBAHAN EKSTRAK DAUN ALPUKAT (Persea americana, mill) TERHADAP MUTU ORGANOLEPTIK DAN KADAR KALIUM PUDING PISANG
}

\author{
Putri Aulia Arza ${ }^{1}$, Suci Purnama Sari ${ }^{2}$ \\ ${ }^{1}$ Dosen Program Studi S1 Gizi STIKes Perintis Padang \\ ${ }^{2}$ Alumni Program Studi S1 Gizi STIKes Perintis Padang \\ Email :tilla.arza@gmail.com
}

\begin{abstract}
Leaf avocado (Persea americana, mill) and Banana Mas (Moses sp) is a plant that has high potassium content and low levels of sodium. The purpose of this research is to analyze the effect of addition of avocado leaf extract to organoleptic quality and potassium banana pudding level. Type of research is true experimental with completely randomized design method. The data used was obtained directly from 25 semi trained panelists. Data analyzed by using ANOVA, if different real continued with Test Duncan.Addition of Leaf avocadoand Banana Mas affect the levels of acceptance in terms of color, aroma and flavor but does not affect the texture. Addition of eggs also affects the level of potassium. Best assessment results obtained on treated banana with the addition of avocado leaf extract as much $250 \mathrm{ml}$ (). Potassium content of pudding with adding leaf avocado 0, 200ml dan $250 \mathrm{ml}$ respectively 0,0365 \%, 0,0577 \%, $0,0790 \%$
\end{abstract}

Keywords: Avocado Leaf, Banana mas, Potassium, Organoleptic Quality).

\section{PENDAHULUAN}

Hipertensi atau yang lebih dikenal dengan nama penyakit darah tinggi adalah suatu keadaan dimana terjadi peningkatan tekanan darah di atas ambang batas normal yaitu 120/80 mmHg. Menurut World Health Organization (WHO), batas tekanan darah yang masih dianggap normal adalah kurang dari 130/85 mmHg. Bila tekanan darah sudah lebih dari 140/90 mmHg dinyatakan hipertensi (batasan tersebut untuk orang dewasa di atas 18 tahun ) (Adib, 2009).

Prevalensi hipertensi didunia pada tahun 2013 menurut World Health Organization (WHO) yaitu pada penduduk umur > 18 tahun mencapai 1 miliyar orang.
Dimana hipertensi tertinggi di Afrika (46\%) sedangkan prevalensi terendah di Amerika (35\%). Prevalensi hipertensi tahun 2013 yang di dapat melalui pengukuran pada umur $\geq 18$ tahun adalah sebanyak 26,5\% (Riskesdas, 2013). Sumatera Barat merupakan provinsi di Indonesia yang prevalensi hipertensinya cukup tinggi yaitu sebanyak 22,6\% (Riskesdas, 2013). Untuk mengatasi masalah tersebut upaya yang dapat dilakukan adalah penggunaan teknologi pangan dengan memanfaatkan sumber daya yang tersedia di Indonesia, yaitu dengan diversifikasi dan substitusi pangan.

Diversifikasi pangan adalah suatu proses pemanfaatan dan pengembangan suatu bahan pangan sehingga penyediaan 
semakin beragam (Astawan, 2008).Daun alpukat dipercaya dapat menurunkan tekanan darah. Penelitian terhadap daun alpukat menunjukkan bahwa efeknya dalam menurunkan tekanan darah. Penelitian Ramadi (2012) diperoleh bahwa Pemberian Seduhan Daun Alpukat (Persea Americana, Mill) berpengaruh Terhadap Tekanan Darah Pada Pasien Hipertensi Laki-Laki yang Perokok Dengan Bukan Perokok Daun alpukat memiliki kandungan kalium yang tinggi. Kalium diperlukan untuk keseimbangan elektrolit dan mengontrol tekanan darah. Hal ini dapat menjadi dasar penggunaan daun alpukat untuk menyembuhkan tekanan darah tinggi (Nurayu, 2010). Kalium bermanfaat bagi tubuh kita yaitu berfungsi untuk mengendalikan tekanan darah, terapi darah tinggi, serta membersihkan karbondioksida didalam darah (Yaswir dan Ferawati, 2012). Selain daun alpukat, buah pisang juga dapat menurunkan tekanan darah, salah satunya pisang mas (Musa sp).

Pisang mas (Musa sp) merupakan tanaman yang baik tumbuh di daerah pegunungan di Sumatera Barat.

Pisang ini sudah banyak di budidayakan dan di konsumsi (Usman, 2009). Tanaman pisang ini banyak di gemari konsumen karena rasanya yang sangat manis, warna daging buah kuning muda, harum dan agak lunak (Shofiyani dan Budi, 2011). Mengingat buah pisang adalah buah yang kaya akan kalium dan rendah kadar natrium. Peranan kalium yaitu membantu menjaga tekanan osmotik di diruang intrasel sedangkan natrium menjaga tekanan osmotik dalam ruang ekstra sel sehingga kadar kalium yang tinggi dapat meningkatkan ekskresi natrium dalam urin (natriuresis), sehingga dapat menurunkan volume darah dan tekanan darah, namun sebaliknya penurunan kalium dalam ruang intrasel menyebabkan cairan dalam ruang intrasel cendrung tertarik keruangan ekstra sel dan retensi natrium dikarenakan respon dari tubuh agar osmolalitas pada kedua kompartemen berada pada titik ekuilibrium namun hal tersebut dapat meningkatkan tekanan darah (Winarno,2009).

Produksi pisang di Sumatera Barat pada Tahun 2015 yaitu sebanyak 136.952 ton (Badan Pusat Statistik Sumatera Barat, 2015). Mengingat potensi gizi dan ketersediaan daun alpukat dan pisang mas di Indonesia yang berlimpah, maka upaya diversifikasi daun alpukat dan pisang mas menjadi pangan fungsional perlu dilakukan antara lain dengan mengolah seduhan daun alpukat dan pisang mas menjadi puding.

Puding adalah nama untuk berbagai hidangan penutup yang umumnyadibuat dari bahan-bahan yang direbus, dikukus, atau dipanggang (Siti, 2010).Penambahan ekstrak daun alpukat dan pisang mas dalam pembuatan pudding pisang diharapkan dapat menjadi alternatif lain dalam memperoleh asupankalium dan akan meningkatkan daya terima masyarakat terhadap pudding pisang kombinasi seduhan daun alpukat.

Penelitian ini dilakukan dengantujuan menganalisis pengaruh dan perbedaan pengaruh penambahan daun alpukat sebanyak 200ml dan 250ml dari $150 \mathrm{~g}$ pisang mas yang digunakan terhadap 
kualitas warna, aroma, tekstur, dan rasa serta kadar kalium pudding.

\section{METODE PENELITIAN}

Jenis penelitian ini adalah eksperimen dengan melakukan penambahan ekstrak daun alpukat(Persea americana, Mill)dan aplikasinya sebagai puding pisang. Rancangan yang digunakan yaitu rancangan acak lengkap (RAL), yang terdiri dari 3 perlakuan (penambahan daun alpukat $0 \mathrm{ml}, 200 \mathrm{ml}$, dan $250 \mathrm{ml}$ dari $150 \mathrm{~g}$ pisang mas) dan melibatkan 25 orang panelis.

Penelitian ini dilakukan pada bulan Januari - Juli 2017. Proses pembuatan puding pisang dan uji organoleptik dilakukan di labor makanan STIkes Perintis. Sedangkan uji kadar kalium dilakukan di Laboratorium Kimia Kopertis Wilayah X.

\section{Prosedur pembuatan ekstrak daun alpukat dalam bentuk diagram.}

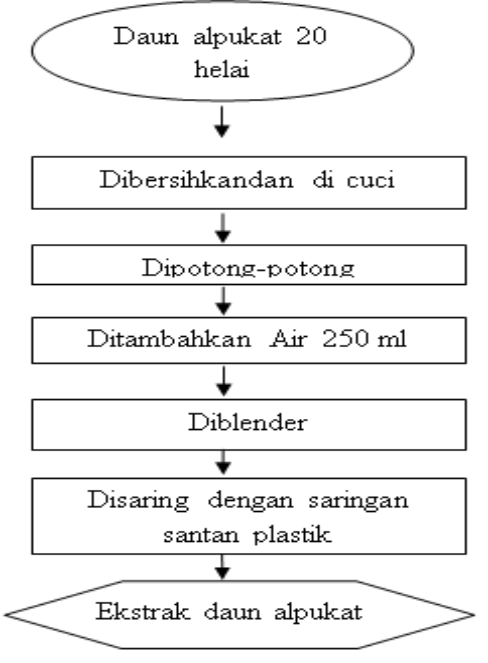

Sumber:Bahatori, D.,2013.

Gambar 1.Diagram Alir Proses Pembuatan Ekstrak Daun Alpukat

\section{HASIL DAN PEMBAHASAN}

Uji organoleptik yang dilakukan terhadap komponen warna, aroma, tekstur dan rasa pada pudding pisang didapatkan hasil sebagai berikut :

\section{Warna}

Berdasarkan hasil uji organoleptik terhadap warna pada pudding pisang dengan menggunakan penambahan ekstrak daun alpukat pada 3 perlakuan dan 2 kali pengulangan, maka didapatkan tingkat kesukaan panelis pada masing-masing perlakuan, seperti pada Tabel 1 dibawah ini :

Tabel 1. Daya Terima Panelis Terhadap Warna Puding Pisang

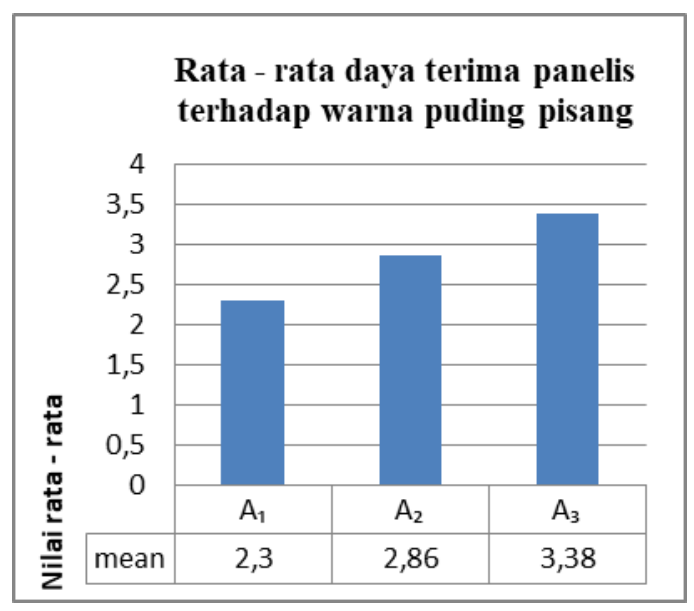

Ket : A1, A2, A3 (Kode Sampel),0-4 (Skala)

Berdasarkan Tabel 1 terlihat bahwa ada kecenderungan peningkatan nilai rata-rata penerimaan panelis terhadap warna pudding pisang dengan peningkatan ekstrak daun alpukat. Nilai rata-rata warna berkisar 2,3 sampai 3,38, dari ketiga perlakuan yang paling disukai panelis adalah perlakuan $\mathrm{C}$ yang merupakan perlakuan Puding pisang dengan 
penambahan ekstrak daun alpukat(150 g : $250 \mathrm{ml}$ ), yang mempunyai rata- rata 3,38. Sedangkan nilai rata-rata terendah yaitu pada perlakuan A dengan nilai 2,3. Gambar diatas menunjukan adanya kecenderungan semakin banyak penggunaan ekstrak daun alpukat, tingkat kesukaan panelis semakin tinggi.

Warna merupakan salah satu faktor yang menentukan mutu dan secara visual warna tampil lebih dahulu dan kadangkadang sangat menentukan, sehingga warna dijadikan atribut organoleptik yang penting dalam suatu bahan pangan (Winarno, 2008). Warna dapat menentukan mutu bahan pangan, dapat digunakan sebagai indikator kesegaran bahan makanan, baik tidaknya cara pencampuran atau pengolahan.

Suatu bahan pangan yang disajikan akan terlebih dahulu dinilai dari segi warna.

Berdasarkan hasil penelitian yang dilakukan pada 3 perlakuan bahwa ekstrak daun alapukat dapat memberikan warna yang menarik pada pudding pisang. Penambahan pewarna pada makanan dimaksud untuk memperbaiki warna makanan yang berubah atau memucat selama proses pengolahan atau memberi warna pada makanan yang tidak bewarna agar kelihatan lebih menarik (Edwin, 2012).

Hasil analisis sidik ragam (Anova) pada taraf 5\% terhadap warna yang menunjukan bahwa perbandingan pudding pisang dengan daun alpukat dengan 2 perlakuan dan 1 kontrol memberikan hasil warna yang berbeda-beda. Warna yang dihasilkan oleh 2 perlakuan, pada umumnya bewarna hijaumuda, dan hijau pekat.

\section{Aroma}

Berdasarkan hasil uji organoleptik terhadap aroma pada pudding pisang dengan menggunakan penambahan ekstrak daun alpukat pada 3 perlakuan dan 2 kali pengulangan, maka didapatkan tingkat kesukaan panelis pada masingmasing perlakuan, seperti pada Tabel 2 dibawah ini :

Tabel 2. Daya Terima Panelis Terhadap Aroma Puding Pisang

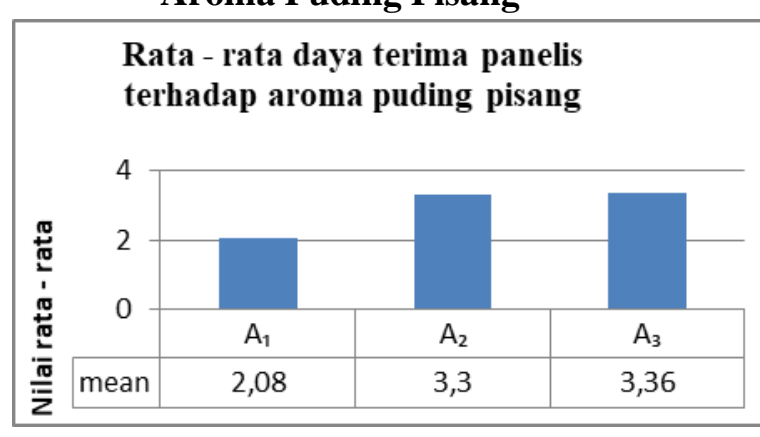

$$
\begin{gathered}
\text { Ket :A1, A2, A3 (Kode Sampel), } 0- \\
4 \text { (Skala) }
\end{gathered}
$$

Berdasarkan Tabel 2 Tingkat kesukaan panelis terhadap aroma pudding pisang berkisar antara 2,08 sampai 3,36. Dari ketiga perlakuan aroma paling disukai panelis adalah perlakuan $\mathrm{C}$, yang merupakan perlakuan pudding pisangdengan penambahan ekstrak daun alpukat (150 g : $250 \mathrm{ml})$.

Aroma makanan banyak menentukan kelezatan makanan tersebut, oleh karena itu aroma merupakan salah satu faktor dalam penentuan mutu (Winarno, 2008).

Aroma yang khas dan menarik dapat membuat makanan lebih disukai 
oleh konsumen sehingga perlu diperhatikan dalam pengolahan suatu bahan makanan. Penggunaan ekstrak daun alpukat pada pembuatan pudding pisang ternyata tidak memberikan pengaruh aroma yang kuat terhadap aroma pudding pisang.Aroma makanan menentukan kelezatan makanan dan kualitas bahan pangan.Aroma merupakan bau yang dikeluarkan oleh makanan atau minuman yang merupakan daya tarik yang sangat kuat dan mampu meransang indera penciuman sehingga mampu membangkitkan selera makan (Winarno, 2008).

Hasil analisis sidik ragam (Anova) pada taraf 5\% terhadap aroma pudding pisang menunjukan bahwa perbandingan pudding pisang dengan ekstrak daun alpukat ada perbedaan nyata.Nilai ratarata tingkat kesukaan panelis terhadap aroma pudding pisang dapat dilihat bahwa semakin tinggi jumlah penggunaan ekstrak daun alpukat maka semakin tinggi nilai penerimaan panelis terhadap pudding pisang. Nilai rata-rata tetinggi adalah perlakuan $\mathrm{C}$ yaitu 3,36.

\section{Tekstur}

Berdasarkan hasil uji organoleptik terhadap aroma pada pudding pisang dengan menggunkan penambahan ekstrak daun alpukat pada 3 perlakuan dan 2 kali pengulangan, maka didapatkan tingkat kesukaan panelis pada masing-masing perlakuan, seperti pada Tabel 3 dibawah ini :

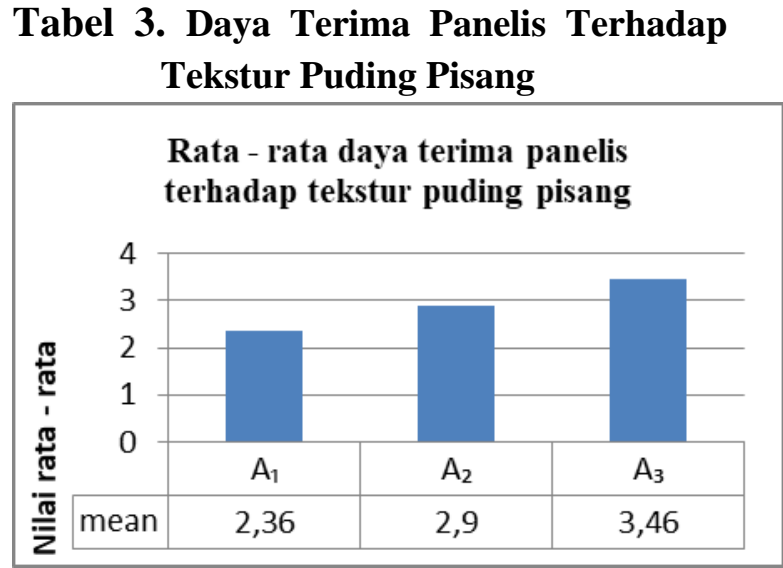

Ket :A1, A2, A3(Kode Sampel), 0-4

(Skala)

Tingkat kesukaan panelis terhadap tekstur pudding pisang berkisar antara 2,36 sampai 3,46.

Dari ketiga perlakuan tekstur yang paling disukai penelis adalah perlakuan $\mathrm{C}$ dimana rata-ratanya 3,46 yang merupakan perlakuan pudding pisang dengan penambahan ekstrak daun alpukat (150 g : $250 \mathrm{ml}$ ).

Hasil penelitian bahwa pudding pisang yang dibuat dengan pewarna alami ekstrak daun alpukat ternyata memberikan pengaruh terhadap tekstur pudding pisang. Tekstur dan kosistensi suatu bahan akan mempengaruhi cita rasa yang ditimbulkan oleh bahan tersebut. Dari hasil penelitian yang dilakukan bahwa perubahan tekstur dapat mengubah rasa karena mempengaruhi kecepatan timbulnya ransangan terhadap sel resptor olfaktori dan kelenjer liur (Winarno, 2008). Hasil akhir makanan yang terdiri dari warna tampilan luar, warna tampilan dalam, kelembutan makanan, bentuk permukaan pada makanan dan keadaan makanan dapat disebut sebagai tekstur makanan. 
Berdasarkan nilai rata-rata tertinggi adalah perlakuan $\mathrm{C}$ yaitu 3,46 dan rata-rata terendah pada perlakuan $\mathrm{A}$ yaitu 2,36. Pada 3 perlakuan setelah dilakukan analisis sidik ragam (Anova) pada taraf 5\% maka menunjukan tidak ada perbedaan nyata atara 3 perlakuan tersebut.

\section{Rasa}

Berdasarkan hasil uji organoleptik terhadap rasa pada pudding pisang dengan menggunkan penambahan ekstrak daun alpukat pada 3 perlakuan dan 2 kali pengulangan, maka didapatkan tingkat kesukaan panelis pada masing-masing perlakuan, seperti pada gambar 5 dibawah ini :

\section{Tabel 4. Daya Terima Panelis Terhadap Rasa Puding Pisang}

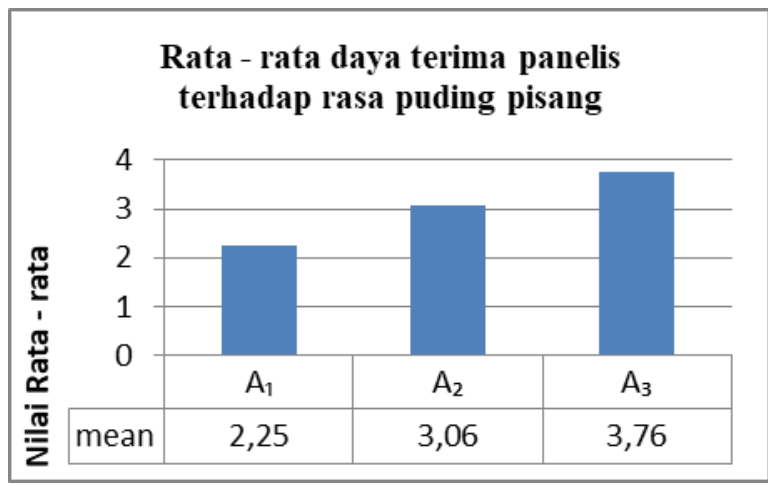

Gambar 5

Ket :A1, A2, A3 (Kode Sampel), 0-4 (Skala)

Tingkat kesukaan panelis terhadap tekstur pudding pisang berkisar antara 2,36 sampai 3,48. Dari ketiga perlakuan tekstur yang paling disukai penelis adalah perlakuan $\mathrm{C}$ dimana rata-ratanya 3,48 yang merupakan perlakuan pudding pisang dengan penambahan ekstrak daun alpukat (150 g : $250 \mathrm{ml}$ ). Ekstrak daun alpukat yang digunakan pada pembuatan pudding pisang ternyata tidak memberikan pengaruh terhadap rasa pudding pisang. Rasa makanan dapat dikenali dan dibedakan oleh kuncup-kuncup kecapan yang terletak pada papilla yaitu bagian noda merah jingga pada lidah. Gerakan lidah akan mempercepat timbulnya respon terhadap rasa (Winarno, 2008). Rasa terbentuk akibat tanggapan paling penting dalam menentuskan keputusan bagi konsumen untuk menerima atau menolak suatu makanan ataupun produk pangan.

Berdasarkan nilai rata-rata tingkat kesukaan panelis terhadap rasa pudding pisang dapat dilihat bahwa semakin tinggi penggunaan ekstrak daun alpukat maka semakin tinggi kesukaan panelis terhadap pudding pisang. Nilai rata-rata tertinggi adalah 3,76 dan terendah 2,25 pada perlakuan A. Pada 3 perlakuan setelah dilakukan analisis sidik ragam (Anova) pada taraf 5\% maka menunjukan bahwa tidak ada perbedaan nyata antar 3 perlakuan tersebut

\section{Formulasi TerbaikPudding Pisang dengan Penambahan Ekstrak Daun Alpukat \\ Pengaruh penambahan esktrak daun alpukat sebagai pewarna terhadap pudding pisang dapat dilihat pada tabel 5}


Tabel 5. Rata - rata penilaian organoleptik pudding pisang dengan penambahan ekstrak daun alpukat :

\begin{tabular}{|c|c|c|c|c|}
\hline Perlakuan & Warna & Aroma & Tekstur & Rasa \\
\hline $\begin{array}{c}\text { Pudding pisang tanpa penambahan } \\
\text { ekstrak daun alpukat150 g : 0 (A) }\end{array}$ & 2,3 & 2,08 & 2,36 & 2,25 \\
\hline $\begin{array}{c}\text { Pudding pisang dengan penambahan } \\
\text { ekstrak daun alpukat150 g : 200 ml (B) }\end{array}$ & 2,86 & 3,3 & 2,9 & 3,06 \\
\hline $\begin{array}{c}\text { Pudding pisang dengan penambahan } \\
\text { ekstrak daun alpukat 150 g : 250 ml (C) }\end{array}$ & 3,38 & 3,36 & 3,46 & 3,76 \\
\hline
\end{tabular}

Berdasarkan hasil uji organoleptic menunjukkan bahwa perlakuan terbaik

Kadar Kalium

Berdasarkan uji kadar kalium adalah perlakuan $\mathrm{C}$ yaitu penambahan pudding pisang yang dilakukan pada tiap daun alpukat sebanyak $250 \mathrm{ml}$.

perlakuan ditetapkan hasil, dapat dilihat pada Tabel 6 berikut :

Tabel 6. Kadar kalium pudding pisang dengan penambahan ekstrak daun alpukat:

\begin{tabular}{|c|c|}
\hline Kode Sampel & \% Kadar Kalium \\
\hline Pudding pisang & $0,0365 \%$ \\
\hline $\begin{array}{c}\text { Pudding pisang dengan penambahan ekstrak } \\
\text { daun alpukat ( } 150 \mathrm{~g}: 200 \mathrm{ml})\end{array}$ & $0,0577 \%$ \\
\hline $\begin{array}{c}\text { Pudding pisang dengan penambahan ekstrak } \\
\text { daun alpukat ( } 150 \mathrm{~g}: 250 \mathrm{ml})\end{array}$ & $0,0790 \%$ \\
\hline
\end{tabular}

Berdasarkan hasil laboratorium dapat dilihat hasil kandungan kalium dalam pudding pisang dengan penambahan ekstrak daun alpukatterjadi peningkatan pada kandungan kadar kalium. Pada pudding pisang dengan penambahan ekstrak daun alpukat (150 g : $250 \mathrm{ml}$ ) kadar kaliumnya yaitu 0,0577\%, sedangkan pada pudding pisang yang ditambahkan ekstrak daun alpukat (150 g :

$250 \mathrm{ml}$ ) kadar kaliumnya sebanyak $0,0790 \%$.

Kadar kalium yang tertinggi terdapat pada perlakuan C. Hal ini disebabkan karena banyaknya penambahan ekstrak daun alpukat pada perlakuan $\mathrm{C}$ dan tingginya kadar kalium pada daun alpukat. penelitian Pudiastuti (2013) diperoleh bahwa kadar kalium 
yang tinggi pada diet berdampak positif terhadap pasien penderita hipertensi.

Asupan kalium idealnya adalah $4.700 \mathrm{mg} / \mathrm{hari}$ dan dapat di peroleh dari buah dan sayur yang mengandung kalium tinggi. Kalium diabsorpsi dengan mudah dalam usus halus.Sebanyak 80-90\% kalium yang di makan di ekskresi melalui urin, selebihnya di keluarkan melalui feses dan sedikit melalui keringat dan cairan lambung. Taraf kalium normal darah di pelihara oleh ginjal melalui kemampuannya menyaring, mengabsorpsi kembali dan mengeluarkan kalium di bawah pengaruh aldosteron. Kalium di keluarkan dalam bentuk ion menggantikan ion natrium melalui mekanisme pertukaran di dalam ginjal. Seperti halnya natrium, kalium mudah sekali di serap oleh tubuh, diperkirakan $90 \%$ dari yang di cerna akan di serap oleh usus kecil. Jumlah kalium yang di konsumsi per hari sekitar 4.500-4.700 per hari (Permenkes, 2013)

\section{KESIMPULAN DAN SARAN}

Terdapat pengaruh peningkatan jumlah ekstrak daun alpukat yang digunakan terhadap warna, aroma dan rasa pudding pisang mas tetapi tidak berpengaruh terhadap tekstur pudding pisang mas. Formulasi terbaik pudding pisang dengan penambahan ekstrak daun alpukat dilihat berdasarkan hasil uji organoleptiknya adalah pudding pisang perlakuan $\mathrm{C}$ yaitu penambahan daun alpukat sebanyak 250ml. Penambahan daun alpukat pada pudding pisang mas ini berdampak terhadap peningkatan kadar kalium pudding.
Semakin banyak ekstrak daun alpukat yang digunakan maka semakin tiggi kadar kalium pudding pisang mas.

Sebaiknya ada penelitian lanjutan yang menganalisis zat gizi secara keselurahan baik makro maupun mikro sehingga pudding pisang mas ini bisa dijadikan sebagai makanan fungsional yang sehat dan bergizi dan tidak hanya bermanfaat untuk penderita hipertensi saja tetapi untuk semua jenis penyakit.

\section{DAFTAR PUSTAKA}

Badan Pusat Statistik Indonesia.2015. Produksi Buah-buahan di Indonesia.

Bahatori, D. 2013. Manfaat Daun Buah dan

BijiAlpukat.https://klinikpengobata nalami.wordpress.com.Diakses pada tanggal 6 Januari 2017.

Pudiastuti, 2013. Pengaruh Tambahan Asupan Kalium dari Diet Terhadap Penurunan Hipertensi Sistolik Tingkat Sedang pada UsiaLanjut. Jurnal Kesehatan Masyarakat Nasional Vol.5, No.3.

Ramadi Afdhal. Perbedaan Pengaruh Pemberian Seduhan Daun Alpukat (Persea Americana, Mill) Terhadap Tekanan Darah Pada Pasien Hipertensi Laki-Laki Yang Perokok Dengan Bukan Perokok Di Wilayah Kerja Puskesmas Padang Pasir Kota; 2012. 
Rizkiyah, N.F 2012, Pengertian Pudding dan Macam-macam Jenis Pudding. $\underline{\text { nurul- }}$ farikhatir.blogspot.co.idDiakses pada Tanggal 29 Desember 2016.

Setyaningsih, D,Apriyantono, A, Sari, M, $P$. 2010.AnalisaSensoriuntukIndustri Pangandan Agro. IPB.Press. Bogor.

Shofiyani A, Gayuh Prasetyo Budi. 2011. Upaya Pengembangan Tanaman Pisang Mas (Musa paradisiacal) Bebas Patogen Melalui Metode Kultur Meristem. AGRITECH, VOL. XIII No.

Tangkilisan, Lizel Rachel, dkk. 2013. Pengaruh Terapi Diet Pisang Ambon (Musa Paradisiaca Var. Sapientum Linn) Terhadap Penurunan Tekanan Darah Pada Klien Hipertensi Di Kota Bitung.ejournal keperawatan (e-Kp) Volume 1. Nomor.

Winarno, 2008.Kimia Pangan Dan Gizi. Penerbit PT Gramedia, Jakarta.

Yaswir, Rismawati dan Ferawati, ira. 2012. Fisiologis dan Gangguan Keseimbangan Natrium, Kalium dan Klorida serta Pemeriksaan Laboratorium. Jurnal FK UNAND Volume 1.Nomor 2. 
